\title{
Asp305Gly mutation improved the activity and stability of the styrene monooxygenase for efficient epoxide production in Pseudomonas putida KT2440
}

\author{
Chunlin Tan ${ }^{1}$, Xian Zhang ${ }^{{ }^{*}}$, Zhijing Zhu ${ }^{2}$, Meijuan Xu1 , Taowei Yang ${ }^{1}$, Tolbert Osire ${ }^{1}$, Shangtian Yang ${ }^{3}$ \\ and Zhiming Rao ${ }^{1 *}$
}

\begin{abstract}
Background: Styrene monooxygenase (SMO) catalyzes the first step of aromatic alkene degradation yielding the corresponding epoxides. Because of its broad spectrum of substrates, the enzyme harbors a great potential for an application in medicine and chemical industries.

Results: In this study, we achieved higher enzymatic activity and better stability towards styrene by enlarging the ligand entrance tunnel and improving the hydrophobicity through error-prone PCR and site-saturation mutagenesis. It was found that Asp305 (D305) hindered the entrance of the FAD cofactor according to the model analysis. Therefore, substitution with amino acids possessing shorter side chains, like glycine, opened the entrance tunnel and resulted in up to 2.7 times higher activity compared to the wild-type enzyme. The half-lives of thermal inactivation for the variant D305G at $60^{\circ} \mathrm{C}$ was $28.9 \mathrm{~h}$ compared to only $3.2 \mathrm{~h}$ of the wild type SMO. Moreover, overexpression of SMO in Pseudomonas putida KT2440 with NADH regeneration was carried out in order to improve biotransformation efficiency for epoxide production. A hexadecane/buffer ( $\mathrm{v} / \mathrm{v})$ biphasic system was applied in order to minimize the inactivation effect of high substrate concentrations on the SMO enzyme. Finally, SMO activities of $190 \mathrm{U} / \mathrm{g}$ CDW were measured and a total amount of $20.5 \mathrm{mM}(S)$-styrene oxide were obtained after $8 \mathrm{~h}$.
\end{abstract}

Conclusions: This study offers an alternative strategy for improved SMO expression and provides an efficient biocatalytic system for epoxide production via engineering the entrance tunnel of the enzyme's active site.

Keywords: Styrene monooxygenase, Biocatalysis, Site-saturation mutagenesis, Epoxide

\section{Background}

Chiral epoxides are a class of high value-added synthons or intermediates with a broad scope of market demand and application in the production of pharmaceuticals, agrochemicals, as well as versatile fine chemicals. Conventionally, epoxides are produced by chemical catalysis. However, this approach presents many shortcomings such as harsh reaction conditions, low selectivity, and

\footnotetext{
*Correspondence: zxshengwu@126.com; raozhm@jiangnan.edu.cn ${ }^{1}$ The Key Laboratory of Industrial Biotechnology, Ministry of Education, School of Biotechnology, Jiangnan University, 1800 Lihu Road, Wuxi 214122, Jiangsu, China

Full list of author information is available at the end of the article
}

many by-products, thus causing significant environmental pollution. Considerable efforts and several enzymatic approaches have been designed by synthetic chemists to overcome these challenges and thus find environmentally friendly alternatives [1-3].

Styrene monooxygenase (SMO, EC: 1.14.14.11), a flavin-dependent enzyme complex consisting of two components (an oxygenase subunit of StyA and a reductase subunit of StyB) [4], was found in several Pseudomonas species and has been used successfully to catalyze styrene to $(S)$-styrene oxide, a valuable chiral intermediate for synthesizing some important pharmaceuticals, such as cilastatin and levamisole $[5,6]$. The SMO, which 
is naturally involved in the upper catabolic pathway of styrene degradation, shows excellent enantioselectivity in the epoxidation of styrene to $(S)$-styrene epoxide with $>99 \%$ ee [7]. This has attracted many efforts to the synthesis of chiral epoxides [8-10]. For example, SMOs from Pseudomonas fluorescens ST and Pseudomonas sp. VLB120 have been used to convert conjugated styrene derivatives as well as aromatic sulfides [11, 12]. Therefore, recombinant SMO expression in E. coli for use in biocatalysis has been investigated by several studies [13].

However, low substrate solubility, low enzyme activity and the consumption of redox equivalents by the SMO are the primary factors restricting its application for epoxide biosynthesis. Several approaches have been developed to solve this problem during the past few decades [14-16]. Wu et al. produced (S)-vicinal diols with more than $99 \%$ ee in recombinant $E$. coli using $10 \%$ ethanol as cosolvent [7]. Furthermore, $\mathrm{Hu}$ et al. used a biphasic $n$-hexanol buffer system to improve the epoxide hydrolase-catalyzed kinetic resolution [15]. The use of a biphasic system in tissue-mediated biotransformation was mainly aimed at overcoming the low water solubilities of substrates and inhibitory effects of products $[17$, 18].

Moreover, the strategies for screening high enzyme activity variants and exploring the efficient biotransformation are also essential. Therefore, Gursky et al. previously undertook the random-library screening approach based on color (indigo) formation [4]. However, this method cannot be easily adapted to detect changes in the substrate preferences of SMOs [19]. Another study on the engineering of the SMO from $P$. putida CA-3 has been performed by screening an error-prone PCR (epPCR) library using the indigo assay [4]. However, the method carries the risk of generating mutants with increased activity only towards the analog substrate indigo, but not the target substrate styrene [20]. Assays based on the reaction of 1,2-diols or on the reaction of epoxides with 4-nitrobenzyl-pyridine might be suitable for this purpose $[19,21]$. The NBP assay provides a sensitive method for detection on paper and thin-layer chromatograms and for quantitative colorimetric analysis of many epoxides of biological, chemical and environmental significance [22]. In this study, a new high throughput screening method based on NBP assay and error prone PCR was established for improved screening of high enzyme activity mutants. Such mutants harbor a great potential for an application in epoxide biosynthesis.

Based on this screening method, a valuable protocol was provided combining random mutagenesis, sitedirected mutagenesis and site-saturation mutagenesis. To discuss the results of this mutation studies, the X-ray crystal structure of the SMO from Pseudomonas putida S12 (PDB ID: 3IHM) [23] was used to provide insight into the putative substrate and flavin-binding pockets as well as to model the cofactor FAD docking into the putative active cavity of the SMO from Pseudomonas sp. SN1. Afterwards, the expression of the native SMO as well as the mutants in E. coli and Pseudomonas was investigated as shown in Fig. 1. Finally, a hexadecane/buffer biphasic system was identified as most-promising two-phase system and used to apply these enzymes obtained in whole cells for an application to gain chiral epoxides.

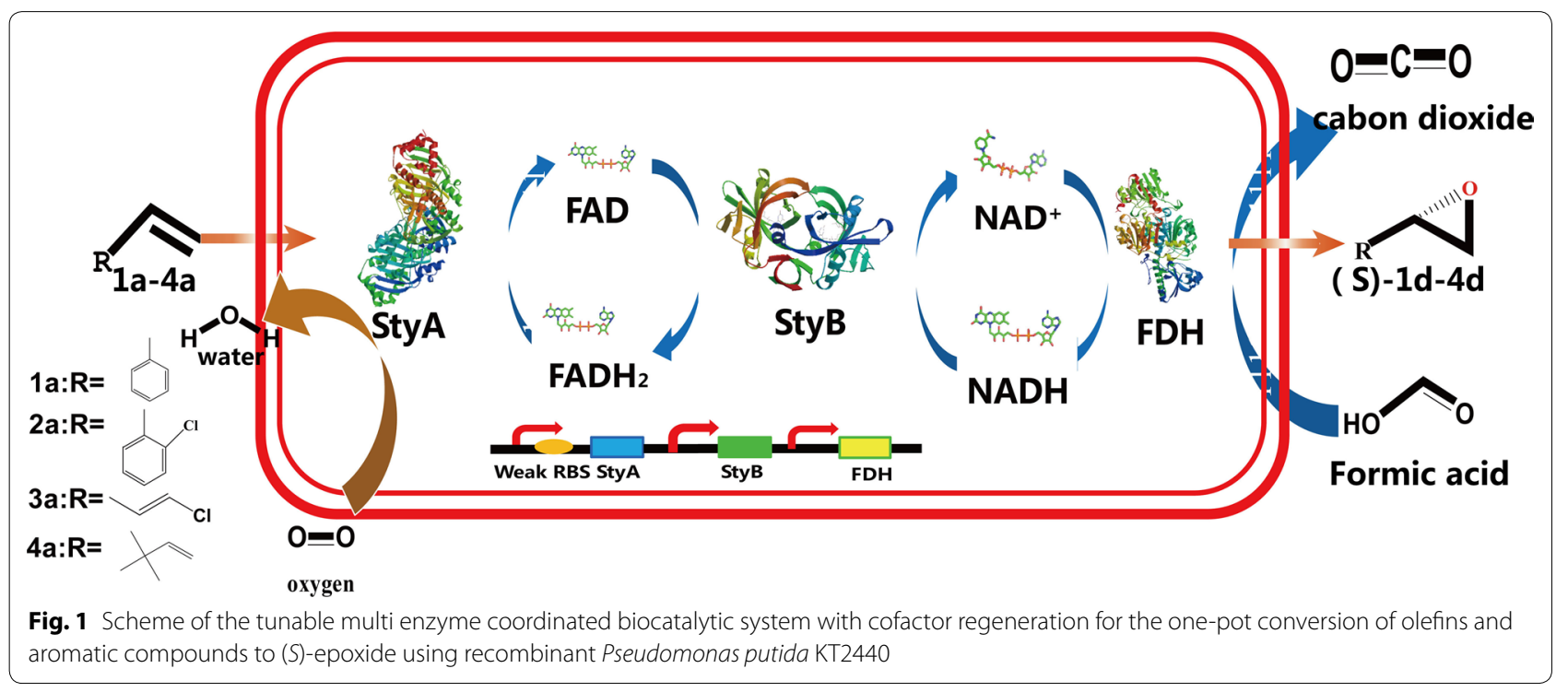




\section{Results and discussion}

Screening for high enzyme activity mutants from epPCR library

The sty $A B$ gene (Gene ID: DQ177365.1) encoding for SMO from Pseudomonas putida SN1 CGMCC1.2309 was used as a template. The enzyme activity of the SMO derived from Pseudomonas putida SN1 was low, with a particularly poor thermostability [24]. In order to improve the SMO activity and thermostability of the enzyme expressed in $E$. coli as well as to attenuate its degree of inactivation in the reaction, a new approach was developed in 96-deep well plates to screen high enzyme activity variants based on color rendering between the epoxide and 4-nitrobenzyl pyridine (4-NBP) from a random mutagenesis library containing more than 2000 SMO mutants [19]. Approximately 56 positive clones with improved color formation on the 96-well plates were identified. However, there were only two mutants with confirmed improved catalytic activity (121\% and 195\%) compared to the wild type enzyme. At this stage, the mutant with the highest enzyme activity was selected for further optimization. This mutant contained three substitutions D305V, V53G and S189I, defined as A (D305V/ V53G/S189I). The new variant with three-site mutations was used as the template for the second round of epPCR. Screening of more than 1000 colonies yielded no positive colonies with improved enzyme activity when compared to those from the first round of epPCR.

Site-directed mutation on the three substitutions D305V, V53G and S189I was then carried out in order to verify which substitution had direct effect on enzyme activity. By constructing three single mutations, we found that only the substitution of D305V had significantly enhanced the enzymatic activity, and the other two substitutions of V53G, S189I did not show any significant increase in enzyme activity compared to the wild type (Fig. 2).

\section{Site-saturation mutagenesis at residue D305} and discussion of the results by structural docking analysis Since the catalytic activity of SMOs is highly influenced by FAD-binding sites, the mutation D305 attracted our interest. A 96-clone library was therefore used to screen all possible SMO mutants at position 305 expressed in $E$. coli. Results indicated that two additional mutants possessed better specific activity than the original mutants from epPCR, with mutant D305G particularly having the highest activity, followed by D305A and D305V (Fig. 2). Structural analysis showed that the side chains at residue 305 dramatically influenced the enzymatic activity of the SMO. Based on the putative FAD-binding channel of SMO, the cofactor FAD molecule was docked into the

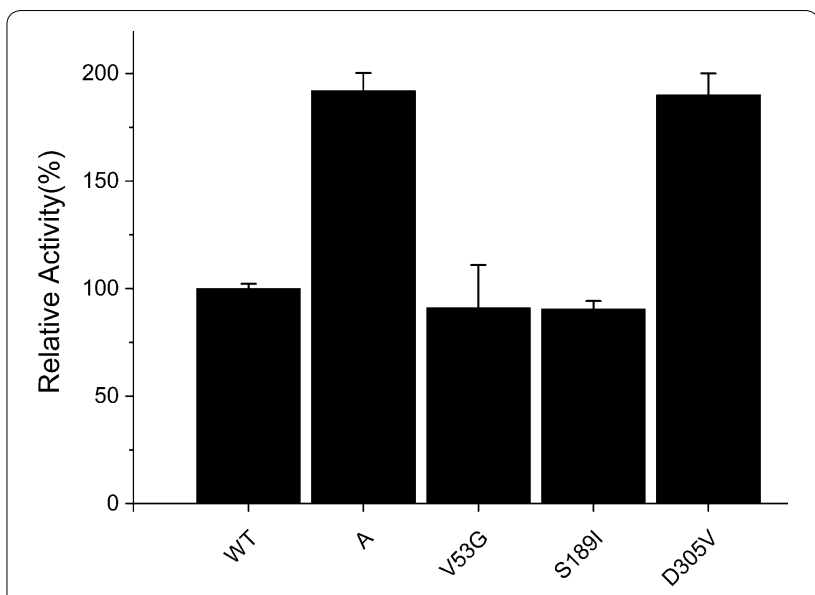

Fig. 2 Biotransformation of styrene by the wild type and the mutations. The whole cell biotransformation with the recombinant cells of BL21/pET-28a-styAB-fdh and its variants were carried out in $50 \mathrm{~mL}$ flasks with $10 \mathrm{~mL}$ of the KP buffer ( $200 \mathrm{mM}$, pH 8.0) containing $26 \mathrm{mM}$ of substrate styrene and $1.0 \mathrm{~g}$ cell (dry cell weight) with addition of $50 \%\left(\mathrm{v} / \mathrm{v}\right.$ ) hexadecane at $30^{\circ} \mathrm{C}$ and $220 \mathrm{rpm}$ on a rotatory shaker for $15 \mathrm{~min}$. The organic phases were combined, dried with anhydrous sodium sulfate, and subjected to the reverse phase HPLC analysis on a Luna $\mathrm{C}_{18}$ column (flow rate: $0.8 \mathrm{~mL} / \mathrm{min}$, methanolwater mixture at a ratio of 75:25). Activities were normalized as percentages of the activity of the wild type. 100\% corresponds to an initial activity of $72 \pm 10 \mathrm{U} / \mathrm{g}$ CDW. The variant of A depicts mutation of V53G/S189I/D305V derived by site-directed mutagenesis of the epPCR library. The mutation of V53G, S189I and D305V were derived by site-directed mutagenesis. All assays were performed in triplicate and the standard deviations of the biological replicates are represented by error bars

protein structure using Autodock 4.0 [25]. The returned 20 results were analyzed by MGL tools 1.5 .4 and the structure with the highest binding energy score was chosen [26]. As shown in Fig. 3a, b, the amino acid residue D305 is located at the entry of the FAD-binding site and probably plays a very crucial role in catalytic activity [27]. Indeed, it was observed that the residue D305 side chain in the wild type was relatively large and thus hindered access of FAD into the tunnel (indicated as the red region in Fig. 3a), while the side chain of the positive mutant D305G is smaller than that of the wild type and, hence, easily allowed FAD docking into the cavity (Fig. 3b). Flavins are key cofactors in the reductive activation and transfer of oxygen atoms to organic substrates in the biosynthesis of olefins as well as aromatic compounds [28, 29]. As shown in Fig. 3c, the amino acid residue D305G was adjacent to the cofactor FAD. It is well known that residues which are adjacent to the substrate or coenzyme act an important role in catalytic activity [30-32]. As shown in Fig. 3d, it was observed that the amino acid residues of Fig. $3 \mathrm{c}$ are the internal structure of the Fig. 3b. Compared with the Asp, the substitution by Val removed the carboxyl acid moiety, however steric hindrance still existed. In summary, results indicated that this structural 

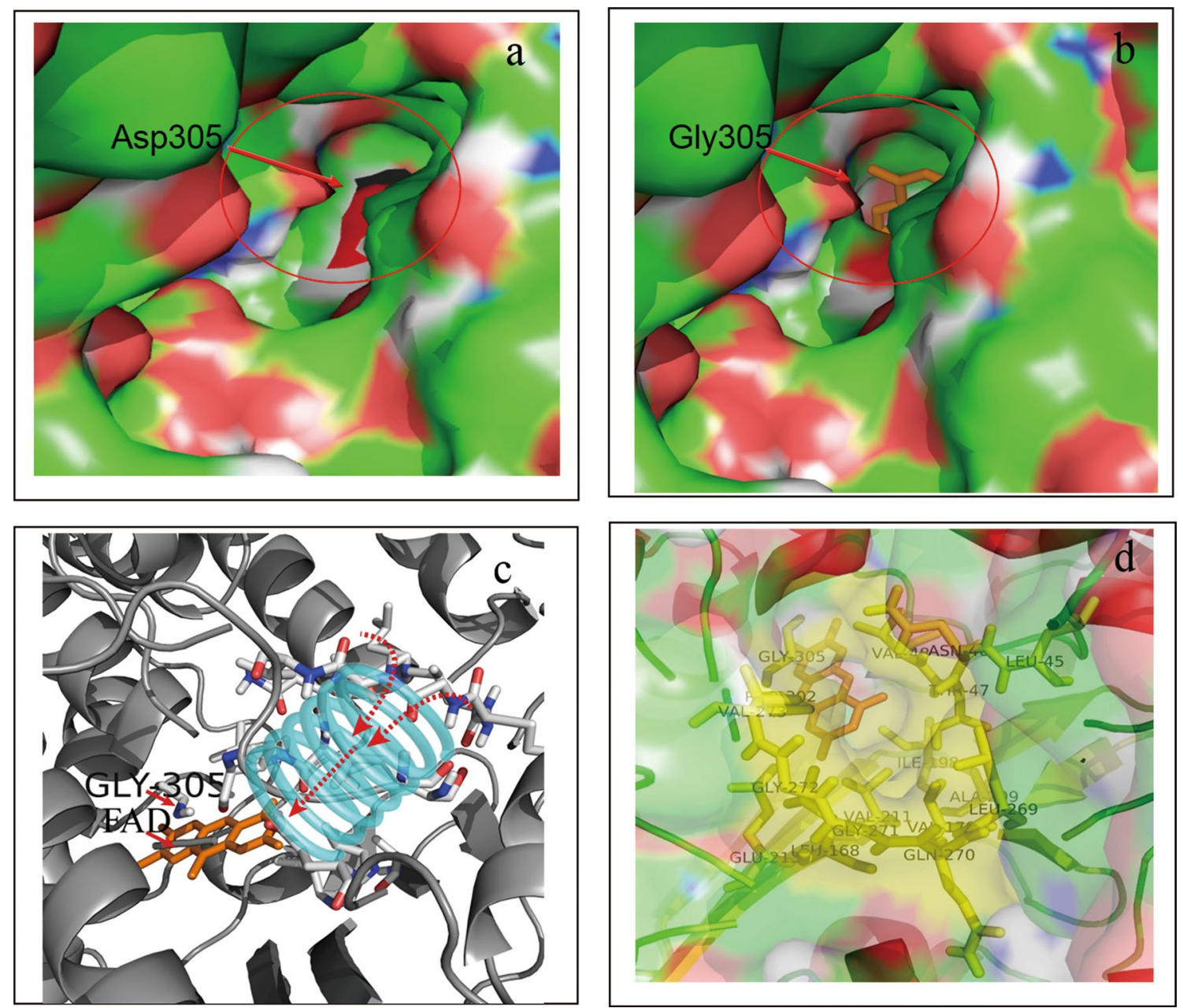

Fig. 3 The orientation of FAD docked into the putative active site of SMO (PDB ID: 3IHM). a The structure of wild-type SMO (Residue D305G is shown in red of the circle). $\mathbf{b}$ The structure of the D305G mutant. c The channel that interacts with FAD. $\mathbf{d}$ The channel of residues in the internal structure. The positions of residues predicted to interact with FAD are shown in yellow (the residues Leu45, Val48, Val170, Val211, Leu269, Glu271, Glu272, Glu271, Glu272, Glu213, and Pro302). FAD is shown in orange by the stick mode. The figure was generated using Autodock 4.0 and displayed by Pymol. The number of Autodock 4GA runs was increased from 20 to 40, the docking grids were set as $20 \times 22 \times 22 \AA$ for styrene and $27 \times 30 \times 28 \AA$ for flavine adenine dinucleotide

modification (D305G) decreased the steric hindrance with its missing side chain, making it easier for FAD to access the ligand tunnel with additional space. It can be strongly supposed that these aspects led to an increased catalytic activity with 3.5 times higher $k_{\text {cat }} / K_{\mathrm{m}}$ values than that of wild type.

Furthermore, it is well recognized that hydrophobicity of the active site tunnel is an important factor in determining the enzymatic specificity and stability [33]. Structural analysis of the large cavity forming the FAD binding site and the ligand tunnel showed that these structures are completely buried within many hydrophobic residues and only few hydrophilic residues (Fig. 3c, d) which is consistent with the hydrophobic nature of the substrate styrene [23]. Therefore, hydrophobic interactions appeared to be crucial at position 305. Replacement of the Asp residue with Gly or Ala increased the enzyme activity, while the loss of the hydrophobic side chain resulted in significantly decreased activity for D305S, D305T as well as in the case of the wild type itself (Fig. 4).

\section{Expression and purification of wild type and mutant enzymes}

The wild type and mutants were all expressed in E. coli BL21 and induced with IPTG as mentioned in "Materials and methods". Three clear bands with a molecular weight of about $45 \mathrm{kDa}$ for StyA, $19 \mathrm{kDa}$ for StyB and $43 \mathrm{kDa}$ for formate dehydrogenase (FDH: EC 1.2.1.2), respectively, 


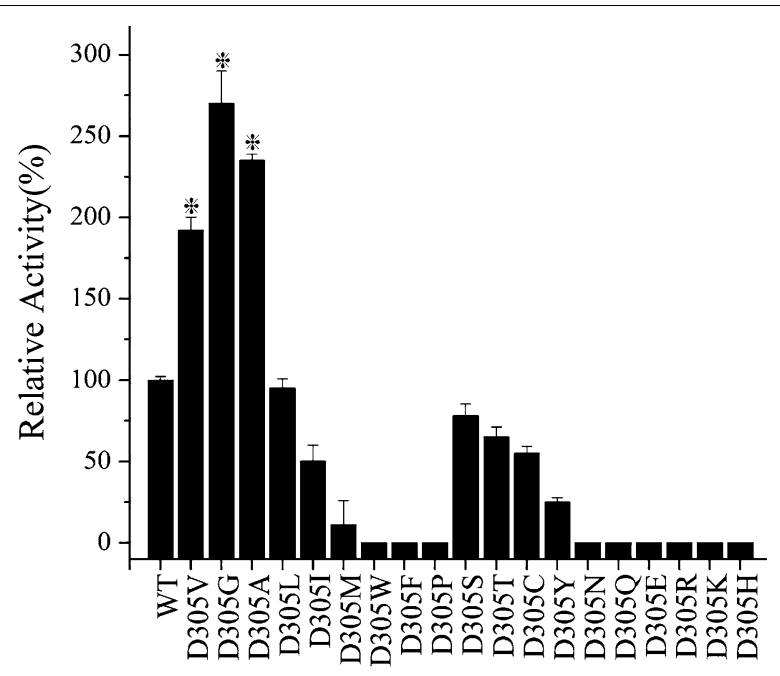

Fig. 4 Biotransformation of styrene by the wild type and the site-saturation mutations at D305. The whole cell biotransformation was conducted by the recombinant cells of

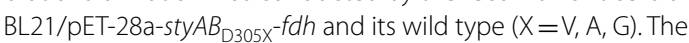
reaction was carried out in $50 \mathrm{~mL}$ flasks with $10 \mathrm{~mL}$ of KP buffer (200 mM, pH 8.0) containing $26 \mathrm{mM}$ of substrate styrene and $1.0 \mathrm{~g}$ cell of dry weight with addition of $50 \%(\mathrm{v} / \mathrm{v})$ hexadecane at $30^{\circ} \mathrm{C}$ and $220 \mathrm{rpm}$ on a rotatory shaker for $15 \mathrm{~min}$. After incubation, the product was withdrawn and subjected to the reverse phase HPLC analysis. The reaction mixture was used to determine specific epoxidation activities. The enzyme activity of wild type was set to $100 \%$, corresponding to the initial activity of $72 \pm 10 \mathrm{U} / \mathrm{g}$ CDW. All assays were performed in triplicate and the standard deviations of the biological replicates are represented by error bars were observed after the $6 \times$ His tagged purified protein was analyzed by $15 \%$ SDS-PAGE. The $\mathrm{NAD}^{+}$-dependent FDH was expressed in this study for NADH regeneration in order to avoid the need for addition of external NADH which is required for the efficient conversion of the substrate by SMO [34]. On the other hand, this homodimeric enzyme could catalyze the oxidation of formate ion to carbon dioxide. Because of that, by-product formation could be minimized. The $s t y B$ gene was inserted into the pET-28a plasmid and expressed in E. coli BL21 (DE3) as C-terminal His6-tagged protein; otherwise most of the StyB proteins would be expressed in the form of insoluble inclusion bodies. It is well known that there is a lengthy sequence in front of the multiple cloning site of pET-28a, including the N-terminal His-tags, which may cause incorrect folding of the protein. Therefore, we removed the $\mathrm{N}$-terminal His-tags and changed it to the C-terminus. In order to realize that, the PCR products were purified and digested with $\mathrm{NcoI}$ and HindIII at $37{ }^{\circ} \mathrm{C}$ for $45 \mathrm{~min}$, then ligated into the pET-28a vector, which was also digested with the same endonucleases. The products were then transformed into E. coli BL21 (DE3), plated on Luria-Bertani (LB) agar. These changes improved $s t y B$ gene expression obtaining more than $60 \%$ of StyB as soluble protein (Fig. 5). The purified StyA, StyB and FDH were used for testing the enzyme properties. Certainly, there were also some other useful ideas for recovering the $S t y B$ protein by resolubilization from

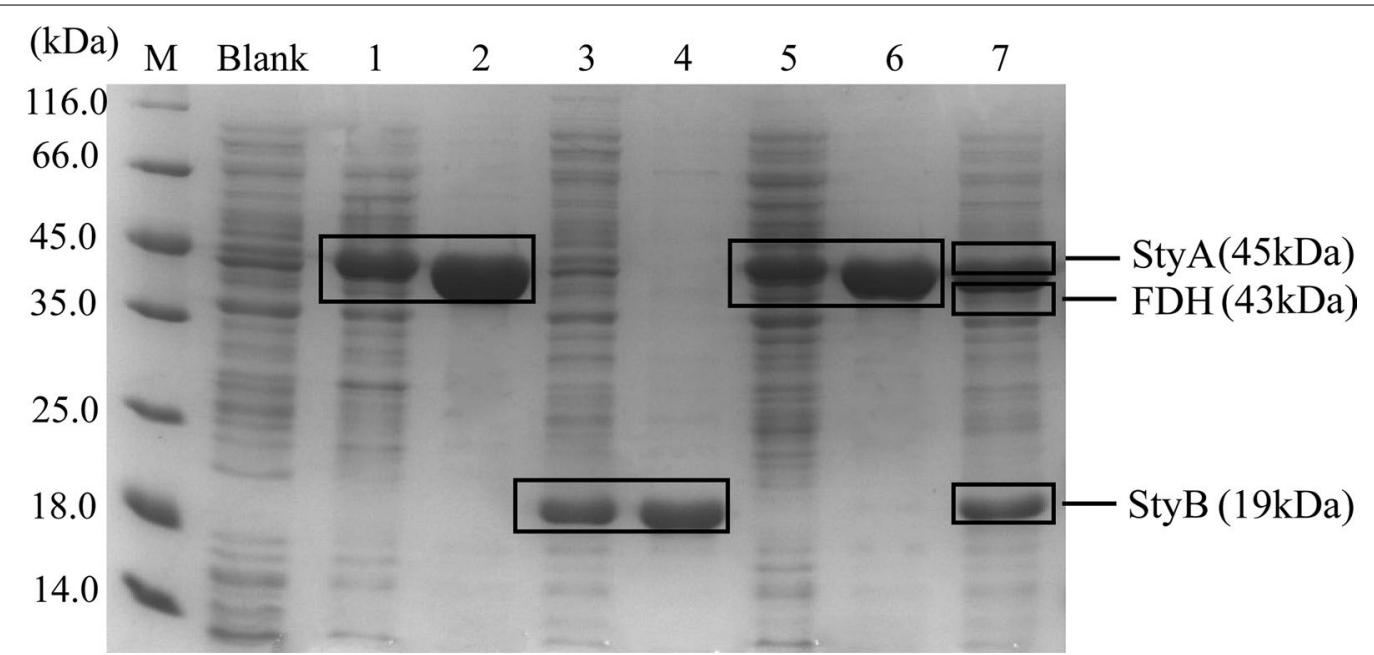

Fig. 5 SDS-PAGE analysis of the overexpression of StyA, StyB and FDH in different hosts. The following samples and markers are shown: M, protein marker; Blank, whole cell protein of control E. coli; Lane 1, whole cell protein of E. coli-pET28a- styA; Lane 2, purified proteins of E. coli-pET28a-styA; Lane 3, whole cell protein of E. coli-pET28a-styB; Lane 4, purified proteins of E. coli-pET28a-styB; Lane 5, whole cell protein of E. coli-pET28a-fdh; Lane 6, purified proteins of E. coli-pET28a-fdh; Lane 7, whole cell protein of Pseudomonas putida KT2440/pJB861-styAB-fdh 
inclusion bodies [35]. Moreover, the solubility or purification results were all the same among the mutations. Finally, the recombinant plasmids pJB861/sty $A B_{\mathrm{D} 305 \mathrm{X}^{-}}$ $f d h$ were constructed and transformed it into competent cells of Pseudomonas putida KT2440 by electroporation $(\mathrm{X}=\mathrm{V}, \mathrm{A}, \mathrm{G})$, as shown in Fig. 5. The recombinant strains of Pseudomonas putida KT2440/pJB861/styAB $B_{\mathrm{D} 305 \mathrm{X}}-f d h$ $(\mathrm{X}=\mathrm{V}, \mathrm{A}, \mathrm{G})$ were then used for the whole cell biotransformation of the native substrate styrene and other short chain compounds such as 3-allyl chloride.

\section{Enzyme characterization of SMO}

Temperature and $\mathrm{pH}$ are very important parameters that influence enzyme activity and stability. The purified enzyme samples (wild type and mutant) expressed in $E$. coli, were used to determine the effect of temperature, $\mathrm{pH}$, and thermostability on the SMO enzyme. In this assay, $200 \mathrm{mM}$ potassium phosphate buffer containing the substrate and co-substrate were used to suspend the purified protein. $2 \mathrm{~mL}$ of the mixture were incubated in $10 \mathrm{~mL}$ flasks on the rotary shaker for $1 \mathrm{~h}$. To identify the optimum temperature for styrene conversion, the temperature during the biotransformation of styrene with the wild type SMO was adjusted from 5 to $45^{\circ} \mathrm{C}$ and the maximum activity was finally observed at $30{ }^{\circ} \mathrm{C}$ (Additional file 1: Figure S3a). The enzyme activity in presence of these temperatures significantly dropped at higher reaction temperatures above $35^{\circ} \mathrm{C}$ (Additional file 1: Figure S3a). Based on that, a temperature of $30{ }^{\circ} \mathrm{C}$ was used for all subsequent activity measurements. In the case of thermostability (=12-h-pre-incubation of native SMO and variants at different temperatures before styrene addition/activity assay; see Fig. 6a), there was no significant difference between the wild type and the variants below $40{ }^{\circ} \mathrm{C}$. However, the substitutions D305V, D305A and D305G resulted in a large improvement in thermostability with the $\mathrm{Tm}$ values of $47.5{ }^{\circ} \mathrm{C}, 54.8^{\circ} \mathrm{C}, 59.8{ }^{\circ} \mathrm{C}$, respectively, which were higher than that of the wild type SMO $\left(44.2{ }^{\circ} \mathrm{C}\right)$. As shown in Fig. 6b, the variants D305V, D305A, D305G were more stable than the wild type at $60{ }^{\circ} \mathrm{C}$. The half-lives of thermal inactivation $\left(\mathrm{t}_{1 / 2}\right)$ at $60{ }^{\circ} \mathrm{C}$ for D305V D305A and D305G variants were $24 \mathrm{~h}, 23 \mathrm{~h}$ and $28.9 \mathrm{~h}$ respectively, which correspond to a 7.2-, 7.5- and 9.0-fold increase to that of wild type $(3.2 \mathrm{~h})$. According to the experiments above, the principle $\mathrm{pH}$ optimum for the transformation was determined using the wild type SMO during a preliminary experiment. The optimum reaction $\mathrm{pH}$ of the enzyme was 8.0 (Additional file 1: Figure S3b). Based on that, a $\mathrm{pH}$ of 8.0 was used for all subsequent activity measurements. Afterwards, further $\mathrm{pH}$-stability experiments with the mutants D305V, D305A and D305G were performed by a 12-h-pre-incubation of the enzymes at different $\mathrm{pH}$ values in comparison to the wild type (see Fig. 6c). The subsequent activity measurements revealed that the mutants showed a higher stability under acidic conditions $\mathrm{pH}(\mathrm{pH}$ 5.0) compared to the wild type. As shown in Fig. 6c, the wild type showed poor acid resistance retaining only $45 \%$ residual activity left after $12 \mathrm{~h}$ incubation at $\mathrm{pH}$ 5.0. However, under alkaline conditions ( $\mathrm{pH} 10.0)$, all the mutants and wild type showed residual activity of about $70 \%$ after $12 \mathrm{~h}$ incubation. These results indicated that an improvement of the hydrophobicity of the substrate entrance tunnel contributed not only the improved enzymatic activity, but also the enhanced stability of the enzyme.

\section{Kinetic analysis of the variants and the wild type enzyme towards the substrate styrene}

Kinetic parameters of the purified wild type SMO and the mutants in E. coli expression hosts were measured using different concentrations of the substrate styrene ranging from 0.5 to $16 \mathrm{mM}$. The reactions were carried out in $2 \mathrm{~mL}$ volumes and the apparent $K_{\mathrm{m}}$ and $k_{\text {cat }}$ values were determined from Michaelis-Menten kinetic plots by the software origin 8.5. As shown in Table 1, the mutations D305V, D305A, and D305G demonstrated a better catalytic efficiency with the substrate styrene compared to the wild type enzyme. The variant D305G showed nearly 3.5 times higher $k_{\text {cat }} / K_{\mathrm{m}}$ values than the wild type. All the three substitutions were hydrophobic amino acids with shorter side chains at the entrance of the tunnel, which confirmed the importance of hydrophobicity for the ligand entrance tunnel.

\section{Screening of water-miscible and water-immiscible organic solvents for the application in a SMO-catalyzed biotransformation}

An appropriate biphasic system could be used to improve the biocatalytic efficiency by enhancing the enzyme tolerance to toxic substrate or product [16]. Therefore, biocompatibility of the D305G variant expressed in Pseudomonas putida KT2440 was taken into consideration in order to screen the appropriate organic solvents for the enzyme reaction [36]. Four commonly used water-miscible organic solvents were then selected to determine their effects on SMO at different concentrations (shown in Additional file 2: Figure S2a). The results indicated that $10 \%(\mathrm{v} / \mathrm{v})$ concentration of the four solvents (ethanol, isoamylalcohol, DMSO, isopropanol) had a minimal effect on SMO activity as the enzyme retained more than $87 \%$ of its initial activity. However, when the concentration of the organic solvent was increased, the enzyme activity of the SMO was significantly reduced. When $30 \%$ of the 

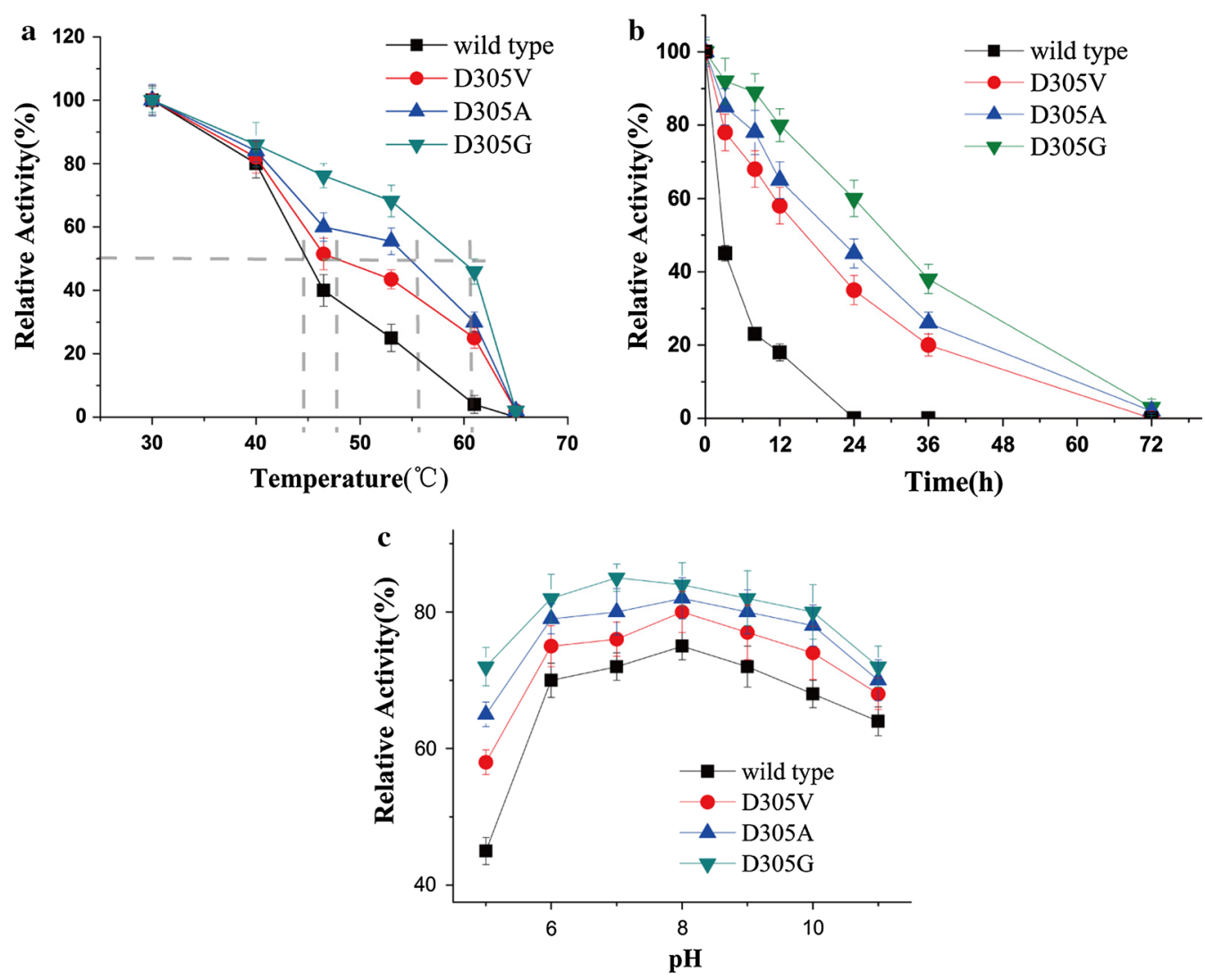

Fig. 6 Enzymatic stability for wild type SMO and its variants in E. coli expression host. Thermal stabilities of the enzymes were carried out by purified enzyme incubation in $\mathrm{KP}$ (potassium phosphate) buffer ( $200 \mathrm{mM}$, pH 8.0) for $12 \mathrm{~h}$ at a range of temperatures from 30 to $65^{\circ} \mathrm{C}$. Afterwards, the residual activity of the pre-incubated SMOs was tested in the following reaction system: $0.8 \mathrm{U} / \mathrm{mL}$ purified SMOA, $1.6 \mathrm{U} / \mathrm{mL}$ of purified SMOB, 1.7 $\mathrm{U} / \mathrm{mL}$ formate dehydrogenase, $0.2 \mathrm{M}$ sodium formate, $0.3 \mathrm{mM} \mathrm{NADH}, 1 \mathrm{mM} \mathrm{NAD}+, 0.05 \mathrm{mM}$ FAD, and $200 \mathrm{mM}$ styrene (from a 200-fold stock in ethanol). And the $\mathrm{pH}$ stability of the wild type and variants was determined by purified enzyme incubation at $30^{\circ} \mathrm{C}$ for $12 \mathrm{~h}$ in the following buffer system: $0.05 \mathrm{M}$ acetate buffer ( $\mathrm{pH}$ 3.0-6.0), $0.05 \mathrm{M}$ phosphate buffer ( $\mathrm{pH}$ 6.0-8.0), and $0.05 \mathrm{M}$ glycine-NaOH buffer (pH 8.0-11.0). After incubation, their residual enzyme activities were measured at $30^{\circ} \mathrm{C}$ in KP buffer $(200 \mathrm{mM}, \mathrm{pH}$ 8.0). a Enzyme inactivation assay at different temperatures for $12 \mathrm{~h}$. b Time courses of thermal inactivation at $60^{\circ} \mathrm{C}$. c Enzyme inactivation assay at different pH for $12 \mathrm{~h}$. The initial activity before incubation was set to 100\%, 100\%-value corresponds to an initial activity of $5.6 \pm 0.21 \mathrm{U} / \mathrm{mg}$. All assays were performed in triplicate and the standard deviations of the biological replicates are represented by error bars

Table 1 The kinetic parameters of mutants screened from site-saturation mutagenesis at position 305 compared to the wild type

\begin{tabular}{llll}
\hline Mutations & $\boldsymbol{K}_{\mathbf{m}}(\mathbf{m M})$ & $\boldsymbol{k}_{\text {cat }}\left(\mathbf{s}^{\mathbf{- 1}}\right)$ & $\boldsymbol{k}_{\text {cat }} / \boldsymbol{K}_{\mathbf{m}}\left(\mathbf{m M}^{-\mathbf{1}} \mathbf{s}^{-\mathbf{1}}\right)$ \\
\hline Wild type & $0.85 \pm 0.12$ & $1.08 \pm 0.03$ & $1.27 \pm 0.15$ \\
D305V & $0.54 \pm 0.08$ & $1.43 \pm 0.03$ & $2.65 \pm 0.17$ \\
D305A & $0.46 \pm 0.11$ & $1.53 \pm 0.02$ & $3.33 \pm 0.21$ \\
D305G & $0.36 \pm 0.14$ & $1.70 \pm 0.02$ & $4.72 \pm 0.33$ \\
\hline
\end{tabular}

The reaction was carried out in $2 \mathrm{~mL}$ volumes containing $0.2 \mathrm{M} \mathrm{KP}$ (potassium phosphate) buffer ( $\mathrm{pH} 8.0), 0.8 \mathrm{U} / \mathrm{mL}$ purified SMOA, $1.6 \mathrm{U} / \mathrm{mL}$ of purified SMOB, $1.7 \mathrm{U} / \mathrm{mL}$ formate dehydrogenase (FDH; EC 1.2.1.2, from Candida boidinii), $0.2 \mathrm{M}$ sodium formate, $0.3 \mathrm{mM} \mathrm{NADH}, 1 \mathrm{mM} \mathrm{NAD}{ }^{+}, 0.05 \mathrm{mM} F A D$, and varying concentrations of styrene (from a 200-fold stock in ethanol). All enzymes were previously expressed in E. coli BL21. The reaction mixture was shaken at $200 \mathrm{rpm}$ and $30^{\circ} \mathrm{C}$ for $1 \mathrm{~h}$, and then it was extracted with ether and analyzed with reverse phase HPLC on a Luna $\mathrm{C}_{18}(4.6 \mathrm{~mm} \times 150 \mathrm{~mm})$ column at a flow rate of $0.8 \mathrm{~mL} /$ $\min$ water-miscible organic solvent was added, the SMO retained $0-12 \%$ of the initial enzyme activity. This phenomenon was probably due to the fact that such polar solvents tend to denature proteins and thus led to the loss of the enzyme activity. The least toxic effect on the SMO activity was observed when $15 \%$ of isoamylalcohol was used in the reaction with the enzyme retaining $90 \%$ of the initial activity in this solvent.

Another approach explored to protect this enzyme against inhibition was addition of a water-immiscible organic solvent to the reaction system (organic solvent/buffer, 1:1). The organic solvent reduces the contact between the enzyme and the substrate, because the biocatalyst remains in the aqueous phase while the substrate accumulates in the organic phase. Thus, 
the substrate toxicity as well as the product inhibition are commonly reduced, and the enzyme activity is enhanced. Among the eight solvents tested (see Additional file 2: Figure S2b), the SMO was very stable in the water-immiscible organic solvents containing hexadecane, $n$-hexane, cyclohexane and bis-(2-ethylhexyl) phthalate (BEHP) retaining more than $75 \%$ of its initial enzyme activity after $8 \mathrm{~h}$ incubation and the SMO showed the lowest stability in dichloromethane $(5 \%)$, followed by toluene (14.5\%), trichloromethane (45\%), ethyl acetate (58.5\%). Ultimately, the following eight biphasic systems were constructed with good biocompatibility to the SMO: 10\% DMSO/buffer, $10 \%$ ethanol/ buffer, $15 \%$ isoamylalcohol/buffer, $10 \%$ isopropanol/ buffer, cyclohexane/buffer (1:1), BEHP/buffer (1:1), hexadecane/buffer (1:1), and $n$-hexane/buffer (1:1). The application of hexadecane was the most effective for $(S)$-styrene oxide production using the recombinant cells of Pseudomonas putida KT2440/pJB861-sty$A B_{\mathrm{D} 305 \mathrm{G}}-f d h$, reaching a maximum activity of $190 \pm 13$ U/g CDW (see Fig. 7), which was 2.4 to 3.5 times higher than that of the other SMOs measured under similar

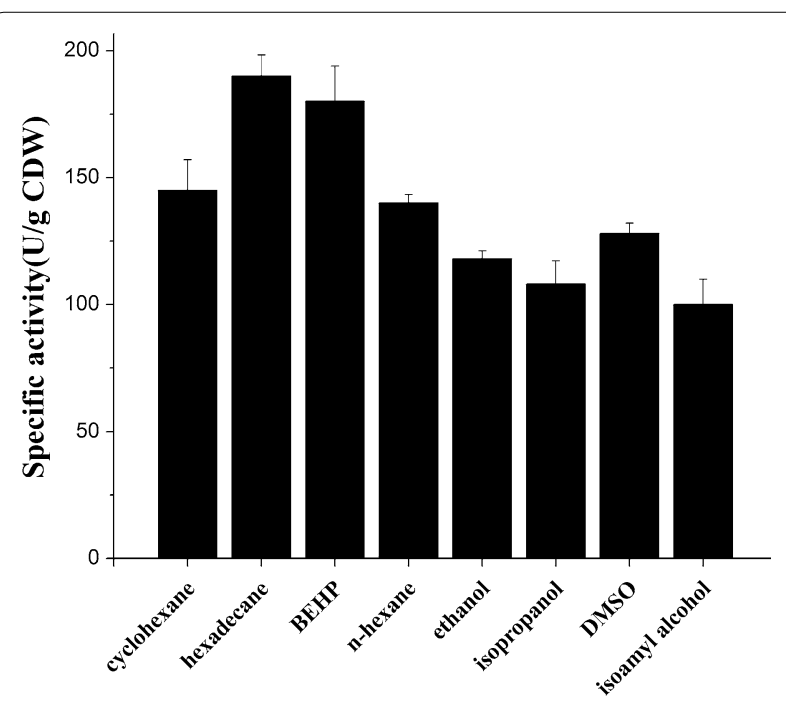

Fig. 7 Biotransformation of styrene to (S)-styrene oxide by whole cells of recombinant Pseudomonas putida KT2440 in different solvents. The whole cell biotransformation was conducted by

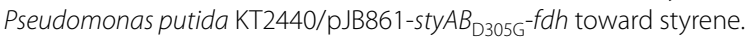
The reaction was carried out in $50 \mathrm{~mL}$ flasks with $10 \mathrm{~mL}$ of KP buffer (200 mM, pH 8.0) containing $26 \mathrm{mM}$ of the substrate styrene and biomass with a cell dry weight of $1.0 \mathrm{~g}$, incubated at $30^{\circ} \mathrm{C}$ for $8 \mathrm{~h}$. And the reaction system was substituted with different water-miscible $(10 \%, v / v)$ and water-immiscible $(1: 1, v / v)$ solvents. The product was withdrawn periodically and analyzed by reverse phase HPLC on a Luna $\mathrm{C}_{18}$ column at a flow rate of $0.8 \mathrm{~mL} / \mathrm{min}$ under a methanolwater mixture at a ratio of 75:25. The reaction mixture after $15 \mathrm{~min}$ was used to determine specific epoxidation activities. All assays were performed in triplicate; each column represents the mean of triplicate assays conditions, such as that from Pseudomonas sp. VLB120 $(79 \pm 5 \mathrm{U} / \mathrm{g} \mathrm{CDW})$ and $P$. putida SN1 ( $55 \pm 5 \mathrm{U} / \mathrm{g} \mathrm{CDW})$ $[6,24]$. In addition, the total amounts of $20.5 \mathrm{mM}(S)$ styrene oxide were reached in $8 \mathrm{~h}$ (as shown in Additional file 3: Figure $\mathrm{S} 6$ ). The average product conversion rate finally reached $2.56 \mathrm{mM} / \mathrm{h}$. This corresponds to a 2.7 -fold higher rate than the rate of another SMO from Pseudomonas putida CA-3 which was measured under similar conditions during a previous study $(0.95 \mathrm{mM} / \mathrm{h})$ [4]. The high yield obtained in this study could be attributed to the effectiveness of the hexadecane system in subduing substrate toxicity and product inhibition on the biocatalytic system. Based on the results above, hexadecane was selected as the best organic solvent for constructing a biphasic system.

\section{Expression of SMO in recombinant Pseudomonas putida KT2440 and application for epoxidation}

The expression of SMO in Pseudomonas putida KT2440 as an alternative host was explored in this study, because this strain is an archetype environmental microbe that has been genetically studied and previously reported as an excellent host for heterologous gene expression [37]. Since the $s t y A B$ gene was derived from the Pseudomonas putida, a Pseudomonas expression host seems to be a promising choice for efficient SMO expression. Furthermore, Pseudomonas putida strains produced rhamnolipids [38]. Such rhamnolipids are anionic biosurfactants that can help to degrade polycyclic aromatic hydrocarbon compounds and emulsify alkanes [39, 40]. They also have a strong ability to reduce surface tension to approximately $30 \mathrm{mN} / \mathrm{m}$ [41], thus enhancing interaction between enzyme and the substrate during biotransformation. In addition, Pseudomonas putida KT2440 is a model environmental microbial strain, which is the most clear and genetically studied Pseudomonas putida strain [42]. It is the preferred host for gene cloning and expression because of its simple and clear genetic operating system. The improved highly efficient electroporation method of P. putida KT2440 has already been established [43]. Based on all of these facts, the recombinant strains Pseudomonas putida KT2440/pJB861-styAB $B_{\mathrm{D} 305 \mathrm{X}}-f d h$ (SMO mutants, $\mathrm{X}=\mathrm{V}, \mathrm{A}, \mathrm{G}$ ) and Pseudomonas putida KT2440/ pJB861-sty $A B-f d h$ (wild type SMO) were constructed to catalyze the transformation of the substrates styrene, 2-chlorostyrene (aromatic compounds) and other important short chain compounds (3,3-dimethyl-1-butene and 3 -allyl chloride). The results showed that the conversion rate of Pseudomonas putida KT2440/pJB861-styAB $B_{\mathrm{D} 305 \mathrm{G}^{-}}$ $f d h$ for the substrates was higher than that in wild type (Table 2). 
Table 2 Substrate conversion and enantiomeric excess for the bioepoxidation of styrene, 3,3-dimethyl-1-butene, 3-allyl chloride and 2-chlorostyrene using the recombinant cells of Pseudomonas putida KT2440 (wild type and mutants) of SMO

\begin{tabular}{|c|c|c|c|c|c|c|c|c|}
\hline \multirow[t]{2}{*}{ Mutant } & & & \multirow[b]{2}{*}{ Conversion (\%) } & \multirow[b]{2}{*}{ ee (\%) } & \multirow[b]{2}{*}{ Conversion (\%) } & \multirow[b]{2}{*}{ ee (\%) } & \multirow[b]{2}{*}{ Conversion (\%) } & \multirow[b]{2}{*}{ ee (\%) } \\
\hline & Conversion (\%) & ee (\%) & & & & & & \\
\hline Wild type & 85 & $>99(S, S)$ & 58 & $71(S, S)$ & 42 & $52(S, S)$ & 76 & $>99(S, S)$ \\
\hline D305A & 93 & $>99(S, S)$ & 67 & $70(S, S)$ & 51 & $48(S, S)$ & 86 & $>99(S, S)$ \\
\hline D305V & 91 & $>99(S, S)$ & 62 & $72(S, S)$ & 48 & $50(S, S)$ & 81 & $>99(S, S)$ \\
\hline D305G & 95 & $>99(S, S)$ & 71 & $70(S, S)$ & 54 & $53(S, S)$ & 97 & $>99(S, S)$ \\
\hline
\end{tabular}

The culture conditions are as follows: the single colonies were grown over $24 \mathrm{~h}$ at $30^{\circ} \mathrm{C}$ in $\mathrm{EM}$ medium containing kanamycin ( $50 \mu \mathrm{g} / \mathrm{mL}$ ). One milliliter of the culture was then inoculated into $100 \mathrm{~mL}$ of EM medium, then cultured at $30^{\circ} \mathrm{C}$ for $24 \mathrm{~h}$ to induce protein expression. The cells were harvested by centrifuging at $8000 \times g$ for 8 min at $4{ }^{\circ} \mathrm{C}$. The whole cell biotransformation with Pseudomonas putida KT2440/pJB861-styAB $B_{\mathrm{D} 305 \mathrm{X}^{-}}$fdh (SMO mutants, $\mathrm{X}=\mathrm{V}, \mathrm{A}, \mathrm{G}$ ) and Pseudomonas putida KT2440/ pJB861-styAB-fdh (wild type SMO) were carried out in $50 \mathrm{~mL}$ flasks containing $10 \mathrm{~mL}$ of $200 \mathrm{mM} \mathrm{KP}$ buffer (pH 8.0 ) with $26 \mathrm{mM}$ of one substrate, dry cell weight of $1.0 \mathrm{~g}$, and $50 \%(\mathrm{v} / \mathrm{v})$ hexadecane, incubated at $30^{\circ} \mathrm{C}$ and $220 \mathrm{rpm}$ on a rotatory shaker for $8 \mathrm{~h}$. The product formation was determined by $\mathrm{HPLC}$ and the conversion was determined for the initial $30 \mathrm{~min}$, as mentioned in "Materials and methods"

\section{Conclusions}

In conclusion, the enzymatic activity of SMO from Pseudomonas sp. SN1 was enhanced by screening and engineering some crucial residues adjacent to its flavine adenine dinucleotide (FAD) binding pocket. A new method for screening high-activity mutants from a random mutant library was designed. Using this method, a three-site mutant with 1.9-fold increased enzymatic activity than that of wild type was obtained. The variant with D305V mutation was the most active one after analyzing the results of site-directed mutagenesis yielding 1.9-fold higher activities than the wild type. Moreover, the docking results showed that the residue D305 was located at the FAD-binding cavity and its large side chain blocked FAD from accessing the cavity and thus played a key role in coenzyme interaction with the active site. Site-saturation mutagenesis at this position 305 resulted in two more mutants (D305A and D305G) with better specific activities (2.3- and 2.7-times, respectively), and higher half-live times during thermal inactivation compared to the wild type. The engineered SMO was also successfully expressed with high yields in Pseudomonas putida KT2440 and E. coli. Finally, aromatic as well as other substrates were transformed with an established hexadecane/buffer biphasic system, and the results indicated decreased substrate toxicity and product inhibition for the mutants. Finally, the average product conversion rate reached $2.56 \mathrm{mM} / \mathrm{h}$ using the mutant D305G, which was 2.7 times higher than that of Pseudomonas putida CA-3 $(0.95 \mathrm{mM} / \mathrm{h})[4]$.

\section{Materials and methods}

Strains, plasmids and chemicals

The sty $A B$ gene (Gene ID: DQ177365.1) encoding SMO from Pseudomonas putida SN1 CGMCC1.2309 was used as a template. Moreover, the two bacterial strains Escherichia coli BL21 and Pseudomonas putida KT2440 were used as hosts for gene (styAB) expression, respectively. The plasmid pET-28a (+) purchased from Invitrogen (Carlsbad, CA) was used for the enzyme expression and mutagenesis studies. The substrates styrene, 3,3-dimethyl-1-butene, 3-allyl chloride and 2-chlorostyrene were purchased from J\&KChemical Ltd. (Shanghai, China). The styrene oxide, epoxy 3,3-dimethyl-1-butene, epoxy chloropropene and 2-chlorostyrene oxide was bought from Sigma-Aldrich Chemical Co. Inc. (Shanghai, China). Prime STAR DNA polymerase was sourced from TaKaRa BioCo. (Dalian, China), 2x Phanta Max Master Mix was bought form Vazyme (Nanjing, China) and other reagents of high quality were obtained from general suppliers in Wuxi. The bacterial strains and plasmids used in this study are listed in Additional file 4: Table S1 whereas all the primers are summarized in Table 3.

\section{Construction of the mutant library}

The mutagenesis library was constructed by error-prone PCR (ep-PCR) according to the manufacturer's instructions of Gene Morph Random Mutagenesis kit [44]. We moderated the frequency of mutation to 2-4 mutations/ $\mathrm{kb}$ by adjusting the concentration of the initial template during the PCR reaction. The primers 5'-ATGAAGAAA CGCATTGGCATTGT- $3^{\prime}$ and $5^{\prime}$-TGCTGCAATGGT CGGTGC-3' were used to construct epPCR libraries of SMO. The recombinant plasmid pET-28a-sty $A$ encoding 
Table 3 Primers used in this work

\begin{tabular}{ll}
\hline Primers & Sequences $\mathbf{5}^{\prime} \mathbf{-} \mathbf{3}^{\prime}$ \\
\hline N46S F & TGGTCTGCGTTTACTGAGCACAGTTGCCCACAATG \\
V48G F & GCGTTTACTGAATACAGGTGCCCACAATGCCGTGA \\
V48Q F & GCGTTACTGAATACACAGGCCCACAATGCCGTGA \\
M186L F & GATTCGCGCAGTGACACTGAGCTTCAGCCCGGGTC \\
M186G F & GATTCGCGCAGTGACAGGTAGCTTCAGCCCGGGTC \\
L269G F & CAGTTCTTTAGACATCGGTCAAGGTGGCGTTGTGC \\
L269V F & CAGTTCTTTAGACATCGTTCAAGGTGCGTTGGC \\
D305A F & CGTTGATCCGGTTCTGGCCCAAGGTGCCAATATGG \\
D305X F & CGTTGATCCGGTTCTGNNNCAAGGTGCCAATATGG \\
R & GCCTTACTGGTTAGCAGAATG
\end{tabular}

The bold type shows the site of the variations. Saturated mutation sites were substituted by bold and italic $\mathbf{N N N}(\mathrm{N}=\mathrm{A} / \mathrm{G} / \mathrm{C} / \mathrm{T})$ ). In addition, all the site of variations share the same downstream primer

wild type styrene monooxygenase was used as the template for the first round of epPCR and the most active mutant from the first round of epPCR was used as template for the second round of epPCR.

The fragments of amplified PCR products were purified and digested by $\mathrm{NcoI}$ and $\mathrm{HindIII}$ at $37^{\circ} \mathrm{C}$ for $45 \mathrm{~min}$ and then ligated into the vector pET28a, which was also digested with the same endonucleases. Then the products were transformed into $E$. coli BL21 (DE3), plated on Luria-Bertani (LB) agar containing $50 \mu \mathrm{g} / \mathrm{mL}$ kanamycin then cultured at $37^{\circ} \mathrm{C}$ for $12 \mathrm{~h}$.

\section{Screening for high-activity variants}

Single colonies from the mutant library were picked from Luria-Bertani (LB) plates containing kanamycin $(50 \mu \mathrm{g} /$ $\mathrm{mL}$ ) and incubated at $37^{\circ} \mathrm{C}$ in 96-well microplates overnight. The overnight bacterial culture $(100 \mu \mathrm{L})$ was then transferred to fresh 96-deep well plates containing LB liquid medium incubated at $37^{\circ} \mathrm{C}$ and $160 \mathrm{rpm}$ for $2 \mathrm{~h}$, induced for enzyme expression with $1 \mathrm{mM}$ IPTG for $2 \mathrm{~h}$ then cultured for $12 \mathrm{~h}$. The cells were harvested by centrifugation at $2260 \times g$ for $10 \mathrm{~min}$. The supernatant was removed from the 96-deep well plates, then the $E$. coli cells were suspended to a cell density of $1.0 \mathrm{~g} \mathrm{cdw} / \mathrm{L}$ in $\mathrm{KP}$ (potassium phosphate) buffer $(0.2 \mathrm{M} \mathrm{pH} 8.0)$ containing glucose $(2 \%, \mathrm{w} / \mathrm{v})$ and $40 \mu \mathrm{L}$ of a substrate stock solution $(0.2 \mathrm{M}$ in ethanol) in a $2 \mathrm{~mL}$ system. The reaction mixture was incubated at $30^{\circ} \mathrm{C}$ for $30 \mathrm{~min}$ with $200 \mathrm{rpm}$ shaking [2].

In a stoppered test tube, $200 \mu \mathrm{L}$ of the reaction mixture was pipetted into a mixed solution containing $800 \mu \mathrm{L}$ of buffer A (buffer A is a mixture of $50 \mathrm{mM}$ $\mathrm{K}_{2} \mathrm{HPO}_{4}-\mathrm{KH}_{2} \mathrm{PO}_{4}, \mathrm{pH} 7.0$ ) and $400 \mu \mathrm{L}$ of $10 \mathrm{mM} 4-\mathrm{NBP}$ (4-NBP is equimolded with an equal volume of ethylene glycol and acetone; the concentration of the mother liquor is $100 \mathrm{mM}$ ) and then reacted at $80{ }^{\circ} \mathrm{C}$ for $10 \mathrm{~min}$ [45]. Afterwards, the mixture was immediately cooled down by ice bathe for $5 \mathrm{~min}$. In addition, $400 \mu \mathrm{L}$ of $50 \%$ (v/v) trimethylamine-acetone buffer were added into the mixture and the total solution turned blue. The samples were subsequently measured by spectrophotometer at an absorbance-wavelength of $565 \mathrm{~nm}$ [46]. The higher specific activity mutants were selected for further studies. E. coli BL21/pET28a-styAB (wild type) was used as a control.

\section{Site-directed and site-saturation mutagenesis}

Site-directed and site-saturation mutagenesis of the sty $A B$ gene at D305 were carried out using whole-plasmid two-step PCR method [47]. The mutation primers used for this are listed in Table 3. Site-saturation mutagenesis at position D305 was accomplished by the degenerate codon of $N N N$ ( $\mathrm{N}$ represents $\mathrm{A}, \mathrm{T}, \mathrm{G}$ or $\mathrm{C}$ ). In addition, the improved fragments of amplified PCR products were purified and digested by $N c o$ I and HindIII at $37^{\circ} \mathrm{C}$ for $45 \mathrm{~min}$ and then ligated into the vector pET28a, which was also digested with the same endonucleases. The recombinant plasmids were finally transformed into E. coli BL21 (DE3) and sequenced by Sangon Biotech to confirm successful mutations.

\section{Structure simulation and molecular docking studies}

The X-ray crystal structure of the oxygenase subunit of P. putida S12 StyA was obtained from the PDB database (PDB ID: 3IHM). The P. putida S12 StyA has 90\% amino acid sequence similarity to that from Pseudomonas putida strain SN1 (Additional file 5: Figure S1). The structure models of the wild type SMO were constructed by homology modeling and downloaded from SWISSMODEL Workspace (http://swissmodel.expasy.org/) [48, 49]. The 3D structure of the styrene ligand and the cofactor flavine adenine dinucleotide (FAD) were downloaded from http://www.chemspider.com/website and prior to docking, all water molecules were removed and nonpolar hydrogen atoms added using MGLTools 1.5.4 [50]. AutoDock 4.2 software (Scripps Institute, California, USA) was used for docking. The number of AutoDock 4GA runs was increased from 20 to 40, the docking grids were set as $20 \times 22 \times 22 \AA$ for styrene and $27 \times 30 \times 28 \AA$ for flavine adenine dinucleotide (FAD) [50]. The 10 independent runs of the ligand-receptor complex from AutoDock 4.2 were calculated by the energy interaction value using MGLTools 1.5.4 and the best docking pose was chosen and visualized by Pymol. 


\section{Expression and purification of recombinant proteins from $E$. coli}

The single colonies were grown overnight at $37{ }^{\circ} \mathrm{C}$ in $\mathrm{LB}$ media containing $50 \mu \mathrm{g} / \mathrm{mL}$ kanamycin. One milliliter of overnight culture was then inoculated into $100 \mathrm{~mL}$ of Luria-Bertani (LB) medium also containing $50 \mu \mathrm{g} / \mathrm{mL}$ kanamycin, then cultured at $37{ }^{\circ} \mathrm{C}$ until the $\mathrm{OD}_{600}$ concentration reached 0.4 . Isopropyl-D-1-thiogalactopyrano side(IPTG)was added to a final concentration of $0.5 \mathrm{mM}$ in medium to induce protein expression. Afterwards, the cells were cultured at $20{ }^{\circ} \mathrm{C}$ for $18 \mathrm{~h}$. The cultures were subsequently harvested by centrifuging at $8000 \times g$ for 8 min at $4{ }^{\circ} \mathrm{C}$.

Recombinant $E$. coli cells (wet weight) treated with lysozyme were lysed by sonication in buffer A, consisting of $0.1 \mathrm{M}$ potassium phosphate ( $\mathrm{pH} 8.0$ ), 20\% glycerol (v/v), $1 \mathrm{mM}$ phenylmethyl sulfonylfluoride (PMSF), $0.5 \mathrm{M}$ potassium chloride, $0.1 \mathrm{mM}$ dithiothreitol (DTT) and $5 \mathrm{mM}$ imidazole [51]. The lysate was centrifuged at $8000 \times g$ for $20 \mathrm{~min}$, and the supernatant was purified in a $1 \mathrm{~mL}$ HisTrapTM HP column on an AKTA purifier system (GE Healthcare, Sweden) with binding buffer (0.02 $\mathrm{M}$ Tris- $\mathrm{HCl}$ bufer and $0.5 \mathrm{M} \mathrm{NaCl}, \mathrm{pH} 7.4)$ at a $0.5 \mathrm{~mL} / \mathrm{min}$ loading rate. The purified protein was eluted at $1 \mathrm{~mL} / \mathrm{min}$ flow rate against a linear gradient of imidazole concentrations in buffer A ranging from 0 to $0.5 \mathrm{M}$. Then, the purified enzymes were pooled for SDS-PAGE analysis. A Bradford protein assay kit was used to determined protein concentration [52].

\section{Enzyme assay and HPLC analytics}

The enzyme activities and the kinetic parameters were determined using purified enzymes from $E$. coli by measuring the formation of styrene oxide using HPLC with $2 \mathrm{~mL}$ volumes, consisting of $0.2 \mathrm{M} \mathrm{KP}$ buffer $(\mathrm{pH}$ 8.0), $0.8 \mathrm{U} / \mathrm{mL}$ of purified SMOA, $1.6 \mathrm{U} / \mathrm{mL}$ of purified $\mathrm{SMOB}, 1.7 \mathrm{U} / \mathrm{mL}$ of purified formate dehydrogenase (FDH: EC 1.2.1.2, from Candida boidinii), $0.2 \mathrm{M}$ sodium formate, $0.3 \mathrm{mM} \mathrm{NADH}, 1 \mathrm{mM} \mathrm{NAD}{ }^{+}, 0.05 \mathrm{mM} F A D$, and varying concentrations of styrene (from a 200-fold stock in ethanol). The reaction mixture was shaken at $200 \mathrm{rpm}$ and $30{ }^{\circ} \mathrm{C}$ for $12 \mathrm{~h}$. Furthermore, the mixture was extracted with ether and analyzed with reverse phase HPLC on a Luna $C_{18}(4.6 \mathrm{~mm} \times 150 \mathrm{~mm})$ column at a flow rate of $0.8 \mathrm{~mL} / \mathrm{min}$. The mobile phase consisted of a methanol-water mixture at a ratio of 75:25. One unit (U) is defined as the activity that produces $1 \mu \mathrm{mol}$ of oxide per min.

Specific epoxidation activities were measured using the whole cells and it was calculated as an average activity based on the amount of product formed in given, constant time with the knowledge of the possibility that substrate conversion is not linear to time during the assay period [24, 53]. Experiments were repeated at least three times independently. The recombinant cells of $E$. coli BL21 or Pseudomonas putida KT2440 with $1.0 \mathrm{~g}$ $\mathrm{CDW} / \mathrm{L}$ were resuspended in $10 \mathrm{~mL} \mathrm{KP}$ buffer $(200 \mathrm{mM}$, $\mathrm{pH} 8.0$ ) and $50 \%(\mathrm{v} / \mathrm{v})$ hexadecane containing $26 \mathrm{mM}$ (in organic solvent) of one of the following substrates: styrene, 2-chlorostyrene, 3,3-dimethyl-1-butene or 3-allyl chloride (Additional file 6: Figure S5). Afterwards, the cultures were incubated at $30{ }^{\circ} \mathrm{C}$ for $8 \mathrm{~h}$ at $220 \mathrm{rpm}$ on a rotatory shaker and terminated by extraction with ether. The reaction mixture that lasted for $15 \mathrm{~min}$ was used to determine the specific epoxidation activities. The combined organic extracts were dried with anhydrous sodium sulfate and subjected to HPLC analysis. Chemical yields were analyzed by reverse-phase HPLC on a Luna $\mathrm{C}_{18}$ column at a flow rate of $0.8 \mathrm{~mL} / \mathrm{min}$.

\section{Determination of the SMO enzyme properties and kinetics assays}

The optimum temperature of SMO from the E. coli was determined using $200 \mathrm{mM}$ potassium phosphate buffer (pH 8.0) with temperature ranging from 5 to $45^{\circ} \mathrm{C}$. The optimum $\mathrm{pH}$ was measured by assaying the enzyme activity at various $\mathrm{pH}$ values $(0.05 \mathrm{M}$ acetate buffer, $\mathrm{pH}$ 3.0-6.0; $0.05 \mathrm{M}$ phosphate buffer, $\mathrm{pH} 6.0-8.0 ; 0.05 \mathrm{M}$ glycine- $\mathrm{NaOH}$ buffer, $\mathrm{pH} 8.0-11.0$ ) at $30{ }^{\circ} \mathrm{C}$. In addition, thermal stabilities of the enzymes were carried out by incubation in KP (potassium phosphate) buffer $(200 \mathrm{mM}$, $\mathrm{pH} 8.0$ ) for $12 \mathrm{~h}$ at a range of temperatures from 30 to $65{ }^{\circ} \mathrm{C}$. The residual enzyme activities of the wild type SMO and its variants after incubation were all measured at $30{ }^{\circ} \mathrm{C}$ in $\mathrm{KP}$ buffer ( $\mathrm{pH}$ 8.0). Furthermore, the FDH with high stability and activity was used as the coenzyme for SMO. When measuring the residual enzyme activity of SMO, an excess of formate dehydrogenase was added to ensure adequate supply of coenzyme. Moreover, the $\mathrm{pH}$ stabilities of the wild type and its variants were determined by purified enzymes incubation at $30{ }^{\circ} \mathrm{C}$ for $12 \mathrm{~h}$ in different buffers with $\mathrm{pH}$ values ranging from 5 to 11 . After incubation, their residual activities were measured in $\mathrm{KP}$ buffer $(0.05 \mathrm{M}, \mathrm{pH} 8.0)$ at $30{ }^{\circ} \mathrm{C}$. For the thermal stabilities and $\mathrm{pH}$ stabilities, only the SMO was pre-incubated at different temperatures or $\mathrm{pH}$ and then the residual enzyme activity was measured at $30{ }^{\circ} \mathrm{C}$ and $\mathrm{pH} 8.0$. However, the FDH (EC 1.2.1.2: formate dehydrogenase) was not incubated at different temperature or $\mathrm{pH}$ values. The Tm value defined as the temperature, at which half of the initial enzyme activity remained, was determined according to the plots of residual relative activity (\%) versus temperature $\left({ }^{\circ} \mathrm{C}\right)$. Activity of wild type $\mathrm{SMO}$ and its variants at $30{ }^{\circ} \mathrm{C}$ in $\mathrm{KP}$ buffer $(0.05 \mathrm{M}, \mathrm{pH} 8.0)$ without incubation was defined as $100 \%$. 
Kinetic parameters of the wild type SMO and variants were determined in $\mathrm{KP}$ buffer $(0.05 \mathrm{M}, \mathrm{pH} 8.0)$ at $30^{\circ} \mathrm{C}$ with varied concentration of the substrate styrene (with concentration range from $0.5 \mathrm{mM}$ to $16 \mathrm{mM}$ ). Kinetic parameters $k_{\text {cat }}$ and $K_{\mathrm{m}}$ were obtained with the help of software Origin 8.5 by plotting enzymatic activity versus substrate concentrations and fitting them using the Michaelis-Menten equation. The parameter $k_{\text {cat }}$ was then calculated according to the following equation: $k_{\text {cat }}=V_{\text {max }} /(\mathrm{E})$, in which (E) means the molar concentration of the enzymes as shown in Additional file 7: Figure S4 [33].

\section{Construction of recombinant Pseudomonas putida KT2440}

One of the improved variants $\operatorname{sty} A B_{\mathrm{D} 305 \mathrm{X}}(\mathrm{X}=\mathrm{V}, \mathrm{A}, \mathrm{G})$ or the wild type were cloned, together with $f d h$, into the expression plasmid pJB861 and the recombinant plasmid $\mathrm{pJB} 861 / s t y A B_{\mathrm{D} 305 \mathrm{X}}-f d h$ or $\mathrm{pJB861/styAB-fdh}$ was transformed into competent Pseudomonas putida KT2440 cells by electroporation in order to find the optimal system for biotransformation of the olefins and aromatic compounds [54]. All positive clones were sequenced by Sangon Biotech. The single colonies were grown over $24 \mathrm{~h}$ at $30{ }^{\circ} \mathrm{C}$ in EM medium containing kanamycin $(50 \mu \mathrm{g} / \mathrm{mL})$. One milliliter of the culture was then inoculated into $100 \mathrm{~mL}$ of EM medium, then cultured at $30^{\circ} \mathrm{C}$ for $24 \mathrm{~h}$ to induce the protein expression. The cells were harvested by centrifugation at $8000 \times g$ for $8 \mathrm{~min}$ at $4{ }^{\circ} \mathrm{C}$.

\section{Screening of organic solvents to construct a biphasic system}

Effects of water-miscible and water-immiscible organic solvents on enzyme activity of SMO were determined to select suitable organic solvents for constructing a biphasic system (Additional file 2: Figure S2). The whole cell biotransformation was performed by using Pseudomonas putida KT2440/pJB861-styAB $B_{\mathrm{D} 305 \mathrm{G}}-f d h$ in presence of styrene. The reaction was carried out in $50 \mathrm{~mL}$ flasks with $10 \mathrm{~mL}$ of $\mathrm{KP}$ buffer (200 mM, pH 8.0) containing $26 \mathrm{mM}$ of the substrate styrene and biomass with a cell dry weight of $1.0 \mathrm{~g}$. The cultures were incubated at $30{ }^{\circ} \mathrm{C}$ for $8 \mathrm{~h}$. All the study conditions were the same except the presence of $10,15,20$ or $30 \%(v / v)$ of ethanol, isopropanol, cyclodextrin or DMSO [55]. The reaction solution without adding any organic solvent was used as a control. Furthermore, the tolerance of SMO in different water-immiscible organic solvents was additionally tested using hexadecane, bis-(2-ethylhexyl) phthalate (BEHP), n-hexane, toluene, dichloromethane, ethyl acetate, trichloromethane and cyclohexane. The reaction mixture containing KP buffer and one of the waterimmiscible organic solvent $(1: 1, \mathrm{v} / \mathrm{v})$ was incubated at $30{ }^{\circ} \mathrm{C}$ for $8 \mathrm{~h}$ with shaking at $220 \mathrm{rpm}$. After incubation, the reaction mixture was terminated by centrifugation. The organic phase was analyzed by HPLC. For the aqueous phase, multiple extractions were performed to ensure complete separation of the product in the organic phase. KP buffer with enzyme, but without any pretreatment of the organic solvent, was used as control. Among all the organic solvents, there are 8 solvents which were used to construct biphasic systems for a biotransformation process at high substrate concentration. Reaction samples $(100 \mu \mathrm{L})$ was withdrawn periodically and analyzed by reverse phase HPLC on a Luna $\mathrm{C}_{18}$ column at a flow rate of $0.8 \mathrm{~mL} / \mathrm{min}$ under a methanol-water mixture at a ratio of $75: 25$.

\section{Additional files}

Additional file 1: Figure S3. Effects of temperature and $\mathrm{pH}$ on SMO activity.

Additional file 2: Figure S2. Effect of water-miscible and water-immiscible organic solvents on SMO activity.

Additional file 3: Figure S6. Time course of biotransformation by the recombinant Pseudomonas putida KT2440/pJB861-styAB $B_{\mathrm{D} 305 \mathrm{G}}$-fdh cells from styrene to styrene oxide.

Additional file 4: Table S1. Strains and plasmids used in this work.

Additional file 5: Figure S1. A section of a multiple-sequence alignment of styA with oxygenases from diverse proteins.

Additional file 6: Figure S5. Biotransformation of $1 \mathrm{a}-4 \mathrm{a}$ to (S)-1d-4d by the whole cell of recombinant Pseudomonas putida KT2440.

Additional file 7: Figure S4. The Michaelis-Menten Plots.

\section{Abbreviations}

epPCR: error-prone PCR; CDW: cells dry weight; KP buffer: potassium phosphate buffer.

\section{Authors' contributions}

CLT, XZ and ZMR conceived and designed the experiments; CLT performed the experiments; MJX, TWY, ZJZ, TO and STY analyzed the data; CLT wrote the paper. All authors read and approved the final manuscript.

\section{Author details}

${ }^{1}$ The Key Laboratory of Industrial Biotechnology, Ministry of Education, School of Biotechnology, Jiangnan University, 1800 Lihu Road, Wuxi 214122, Jiangsu, China. ${ }^{2}$ The School of Digital Media, Jiangnan University, Wuxi 214122, China. ${ }^{3}$ Department of Chemical and Biomolecular Engineering, The Ohio State University, Columbus, $\mathrm{OH}$ 43210, USA.

\section{Acknowledgements}

We thank for the supports by the Project Funded by the Priority Academic Program Development of Jiangsu Higher Education Institutions, Top-notch Academic Programs Project of Jiangsu Higher Education Institutions (TAPP), Ningxia Key Laboratory for Food Microbial-Applications Technology and Safety Control, the 111 Project (111-2-06), and the Jiangsu province "Collaborative Innovation Center for Modern Industrial Fermentation" industry development program. We also would like to thank Vazyme for their excellent technical assistance.

\section{Competing interests}

The authors declare that they have no competing interests. 


\section{Availability of data and materials}

The authors declare that all the data supporting the findings of this study are available within the article and its additional files.

\section{Consent for publication}

Not applicable.

\section{Ethics approval and consent to participate}

Not applicable.

\section{Funding}

This work was funded by the National Natural Science Foundation of China (31500065), Natural Science Foundation of Jiangsu Province (BK20150142) The Fundamental Research Funds for the Central Universities (JUSRP51708A), National first-class discipline program of Light Industry Technology and Engineering (LITE2018-06), Key research and development program of Ningxia hui autonomous region(2017BY069)and The science and technology innovation team foundation of Ningxia hui autonomous region (KJT2017001), the Program of the Key Laboratory of Industrial Biotechnology, Ministry of Education, China (KLIB-KF201703).

\section{Publisher's Note}

Springer Nature remains neutral with regard to jurisdictional claims in published maps and institutional affiliations.

\section{Received: 8 October 2018 Accepted: 17 January 2019}

Published online: 24 January 2019

\section{References}

1. Kuhn D, Kholiq MA, Heinzle E, Bühler B, Schmid A. Intensification and economic and ecological assessment of a biocatalytic oxyfunctionalization process. Green Chem. 2010;12:815-27.

2. Wu S, Chen Y, Xu Y, Li A, Xu Q, Glieder A, Li Z. Enantioselective transdihydroxylation of aryl olefins by cascade biocatalysis with recombinant Escherichia coli coexpressing monooxygenase and epoxide hydrolase. ACS Catal. 2014:4:409-20.

3. Zhou Y, Wu S, Li Z. Cascade biocatalysis for sustainable asymmetric synthesis: from biobased L-phenylalanine to high-value chiral chemicals. Angew Chem. 2016;55:11647-50.

4. Gursky LJ, Nikodinovic-Runic J, Feenstra KA, O'Connor KE. In vitro evolution of styrene monooxygenase from Pseudomonas putida CA-3 for improved epoxide synthesis. Appl Microbiol Biotechnol. 2010;85:995-1004.

5. Clissold SP, Todd PA, Campolirichards DM. Imipenem/cilastatin. A review of its antibacterial activity, pharmacokinetic properties and therapeutic efficacy. Drugs. 1987;33:183-241.

6. Panke S, Witholt B, Schmid A, Wubbolts MG. Towards a biocatalyst for (S)-styrene oxide production characterization of the styrene degradation pathway of Pseudomonas sp. strain VLB120. Appl Environ Microbiol. 1998;64(66):2032.

7. Wu S, Zhou Y, Wang T, Too HP, Wang DI, Li Z. Highly regio- and enantioselective multiple oxy- and amino-functionalizations of alkenes by modular cascade biocatalysis. Nat Commun. 2016;7:11917.

8. Kang LT, Dmytrenko O, Otto K, Schmid A, Schwaneberg U. A p-nitrothiophenolate screening system for the directed evolution of a two-component epoxygenase (StyAB). J Mol Catal B Enzyme. 2008;50:121-7.

9. Park JB, Bühler B, Habicher T, Hauer B, Panke S, Witholt B, Schmid A. The efficiency of recombinant Escherichia coli as biocatalyst for stereospecific epoxidation. Biotechnol Bioeng. 2010:95:501-12.

10. Sello G, Orsini F, Bernasconi S, Gennaro PD. Synthesis of enantiopure 2-amino-1-phenyl and 2-amino-2-phenyl ethanols using enantioselective enzymatic epoxidation and regio and diastereoselective chemical aminolysis. Cheminform. 2006;17:372-6.

11. Bestetti G, Gennaro PD, Colmegna A, Ronco I, Galli E, Sello G. Characterization of styrene catabolic pathway in Pseudomonas fluorescens ST. Int Biodeterior Biodegrad. 2004:54:183-7.
12. Hollmann F, Lin PC, Witholt B, Schmid A. Stereospecific biocatalytic epoxidation: the first example of direct regeneration of a FAD-dependent monooxygenase for catalysis. J Am Chem Soc. 2003;125:8209-17.

13. Zhou Y, Wu S, Li Z. Cascade biocatalysis for sustainable asymmetric synthesis: from biobased L-phenylalanine to high-value chiral chemicals. Angew Chem Int Ed Engl. 2016;128:11819-22.

14. Panke S, Wubbolts MG, Schmid A, Witholt B. Production of enantiopure styrene oxide by recombinant Escherichia coli synthesizing a two-component styrene monooxygenase. Biotechnol Bioeng. 2015;69:91-100.

15. Hu D, Tang CD, Yang BA, Liu JC, Yu T, Deng C, Wu MC. Expression of a novel epoxide hydrolase of Aspergillus usamii E001 in Escherichia coli and its performance in resolution of racemic styrene oxide. J Ind Microbiol Biotechnol. 2015;42:671-80.

16. Panke SD, De Lorenzo V, Kaiser A, Witholt B, Wubbolts MG. Engineering of a stable whole-cell biocatalyst capable of (S)-styrene oxide formation for continuous two-liquid-phase applications. Appl Environ Microbiol. 1999;65:5619-23.

17. Zhang W, Wu J, Li B, Wu H, Wang L, Hao J, Wu S, Zhou Q. Structure-activity \& structure-toxicity relationship study of salinomycin diastereoisomers and their benzoylated derivatives. Org Biomol Chem. 2016;14:2840-5.

18. Yazu K, Yamamoto Y, Furuya T, Miki K, Ukegawa K. Oxidation of dibenzothiophenes in an organic biphasic system and its application to oxidative desulfurization of light oil. Energy Fuels. 2001;15:1535-6.

19. Zocher F, Bornscheuer UT, Hauer B, Schmid RD, Enzelberger MM. A colorimetric assay suitable for screening epoxide hydrolase activity. Analytica Chimica Acta. 1999;391:345-51.

20. Zhang ZG, Liu Y, Guengerich FP, Matse JH, Chen J, Wu ZL. Identification of amino acid residues involved in 4-chloroindole 3-hydroxylation by cytochrome P450 2A6 using screening of random libraries. J Biotechnol. 2009;139:12-8

21. Viviana SF, Denis W, Jean-Louis R. Enzyme assay and activity fingerprinting of hydrolases with the red-chromogenic adrenaline test. Nat Protoc. 2008:3:1270-7.

22. Cheung S, Mccarl V, Holmes AJ, Coleman NV, Rutledge PJ. Substrate range and enantioselectivity of epoxidation reactions mediated by the ethene-oxidising Mycobacterium strain NBB4. Appl Microbiol Biotechnol. 2013;97:1131-40

23. Ukaegbu UE, Kantz A, Beaton M, Gassner GT, Rosenzweig AC. Structure and ligand binding properties of the epoxidase component of styrene monooxygenase. Biochemistry. 2010;49:1678-88.

24. Park MS, Bae JW, Han JH, Lee EY, Lee SG, Park S. Characterization of styrene catabolic genes of Pseudomonas putida SN1 and construction of a recombinant Escherichia coli containing styrene monooxygenase gene for the production of (S)-styrene oxide. J Microbiol Biotechnol. 2006;16:1032-40

25. Ratnayake ND, Liu N, Kuhn LA, Walker KD. Ring-substituted a-arylalanines for probing substituent effects on the isomerization reaction catalyzed by an aminomutase. ACS Catal. 2015;4:3077-90.

26. Lin H, Tang DF, Ahmed AAQ, Liu Y, Wu ZL. Mutations at the putative active cavity of styrene monooxygenase: enhanced activity and reversed enantioselectivity. J Biotechnol. 2012;161:235-41.

27. Ramon-Maiques S, Fernandez-Murga ML, Gil-Ortiz F, Vagin A, Fita I, Rubio V. Structural bases of feed-back control of arginine biosynthesis, revealed by the structures of two hexameric $\mathrm{N}$-acetylglutamate kinases, from Thermotoga maritima and Pseudomonas aeruginosa. J Mol Biol. 2006;356:695-713.

28. Ballou DP, Entsch B, Cole LJ. Dynamics involved in catalysis by singlecomponent and two-component flavin-dependent aromatic hydroxylases. Biochem Biophys Res Commun. 2005;338:590-8.

29. Van Berkel WJH, Kamerbeek NM, Fraaije MW. Flavoprotein monooxygenases, a diverse class of oxidative biocatalysts. J Biotechnol. 2006:124:670-89.

30. Chaloupkova R, Sykorova J, Prokop Z, Jesenska A, Monincova M, Pavlova M, Tsuda M, Nagata Y, Damborsky J. Modification of activity and specificity of haloalkane dehalogenase from Sphingomonas paucimobilis UT26 by engineering of its entrance tunnel. J Biol Chem. 2003;278:52622-8.

31. Hiromoto T, Fujiwara S, Hosokawa K, Yamaguchi H. Crystal structure of 3-hydroxybenzoate hydroxylase from Comamonas testosteroni has a large tunnel for substrate and oxygen access to the active site. J Mol Biol. 2006:364:878-96 
32. Smeulders MJ, Barends TRM, Pol A, Scherer A, Zandvoort MH, Udvarhelyi A, Khadem AF, Menzel A, Hermans J, Shoeman RL, et al. Evolution of a new enzyme for carbon disulphide conversion by an acidothermophilic archaeon. Nature. 2011;478:412.

33. Zhou J, Wang Y, Chen J, Xu M, Yang T, Zheng J, Zhang X, Rao Z. Rational engineering of Bacillus cereus leucine dehydrogenase towards a-keto acid reduction for improving unnatural amino acid production. Biotechnol $\mathrm{J}$. 2018. https://doi.org/10.1002/biot.201800253

34. Zheng J, Yang T, Zhou J, Xu M, Zhang X, Rao Z. Elimination of a free cysteine by creation of a disulfide bond increases the activity and stability of Candida boidinii formate dehydrogenase. Appl Environ Microbiol. 2017:83:e02624

35. Kantz A, Chin F, Nallamothu N, Nguyen T, Gassner GT. Mechanism of flavin transfer and oxygen activation by the two-component flavoenzyme styrene monooxygenase. Arch Biochem Biophys. 2005;442:102.

36. Lotter J, Botes AL, van Dyk MS, Breytenbach JC. Correlation between the physicochemical properties of organic solvents and their biocompatibility toward epoxide hydrolase activity in whole-cells of a yeast Rhodotorula sp. Biotechnol Lett. 2004;26:1191-5.

37. Nelson KE, Weinel C, Paulsen IT, et al. Complete genome sequence and comparative analysis of the metabolically versatile Pseudomonas putida KT2440. Environ Microbiol. 2002;4:799-808.

38. Abdel-Mawgoud AM, Lepine F, Deziel E. A stereospecific pathway diverts beta-oxidation intermediates to the biosynthesis of rhamnolipid biosurfactants. Chem Biol. 2014;21:156-64.

39. Banat IM, Franzetti A, Gandolfi I, Bestetti G, Martinotti MG, Fracchia L, Smyth TJ, Marchant R. Microbial biosurfactants production, applications and future potential. Appl Microbiol Biotechnol. 2010;87:427-44.

40. Sarney DB, Vulfson EN. Application of enzymes to the synthesis of surfactants. Trends Biotechnol. 1995;13:164.

41. Al-Tahhan RA, Sandrin TR, Bodour AA, Maier RM. Rhamnolipid-induced removal of lipopolysaccharide from Pseudomonas aeruginosa: effect on cell surface properties and interaction with hydrophobic substrates. Appl Environ Microbiol. 2000;66:3262.

42. Puchalka J, Oberhardt MA, Godinho M, Bielecka A, Regenhardt D, Timmis KN, Papin JA, dos Santos VAM. Genome-scale reconstruction and analysis of the Pseudomonas putida KT2440 metabolic network facilitates applications in biotechnology. PLoS Comput Biol. 2008;4:e1000210.

43. Iwasaki K, Uchiyama H, Yagi O, Kurabayashi T, Ishizuka K, Takamura Y. Transformation of Pseudomonas putida by electroporation. Biosci Biotechnol Biochem. 1994;58:851-4.
44. Li Y, Yang H, Xu F. Identifying and engineering a critical amino acid residue to enhance the catalytic efficiency of Pseudomonas sp. methyl parathion hydrolase. Appl Microbiol Biotechnol. 2018;102:6537-45.

45. Agarwal SC, Duuren BL, Van Kneip TJ. Detection of epoxides with 4-(p-nitrobenzyl) pyridine. Bull Environ Contam Toxicol. 1979;23:825.

46. Coleman NV, Yau S, Wilson NL, Nolan LM, Migocki MD, Ly MA, Crossett B, Holmes AJ. Untangling the multiple monooxygenases of Mycobacterium chubuense strain NBB4, a versatile hydrocarbon degrader. Environ Microbiol Rep. 2011:3:297-307.

47. Sanchis J, Fernandez L, Carballeira JD, Drone J, Gumulya Y, Hobenreich H, Kahakeaw D, Kille S, Lohmer R, Peyralans JJ, et al. Improved PCR method for the creation of saturation mutagenesis libraries in directed evolution: application to difficult-to-amplify templates. Appl Microbiol Biotechnol. 2008;81:387-97.

48. Biasini M, Bienert S, Waterhouse A, Arnold K, Studer G, Schmidt T, Kiefer F, Cassarino TG, Bertoni M, Bordoli L, Schwede T. SWISS-MODEL: modelling protein tertiary and quaternary structure using evolutionary information. Nucleic Acids Res. 2014;42:W252-8.

49. Simard JR, Getlik M, Grutter C, Pawar V, Wulfert S, Rabiller M, Rauh D. Development of a fluorescent-tagged kinase assay system for the detection and characterization of allosteric kinase inhibitors. J Am Chem Soc. 2009;131:13286-96.

50. Morris GM, Goodsell DS, Halliday RS, Huey R, Hart WE, Belew RK, Olson AJ. Automated docking using a Lamarckian genetic algorithm and an empirical binding free energy function. J Comput Chem. 1998;19:1639-62.

51. Lin H, Qiao J, Liu Y, Wu ZL. Styrene monooxygenase from Pseudomonas sp. LQ26 catalyzes the asymmetric epoxidation of both conjugated and unconjugated alkenes. J Mol Catal B Enzym. 2010;67:236-41.

52. Zhou-Pan XR, Sérée E, Zhou XJ, Placidi M, Maurel P, Barra Y, Rahmani R. Involvement of human liver cytochrome P450 3A in vinblastine metabolism: drug interactions. Cancer Res. 1993;53:5121.

53. Bae JW, Raj SSM, Song EL, Lee SG, Jeong YJ, Park S. Construction and characterization of a recombinant whole-cell biocatalyst of Escherichia coli expressing styrene monooxygenase under the control of arabinose promoter. Biotechnol Bioprocess Eng. 2008;13:69-76.

54. Cho JH, Kim EK, So JS. Improved transfomation of Pseudomonas putida KT2440 by electroporation. Biotechniques. 1995;9(1):41-4.

55. Hu D, Wang R, Shi XL, Ye HH, Wu Q, Wu MC, Chu JJ. Kinetic resolution of racemic styrene oxide at a high concentration by recombinant Aspergillus usamii epoxide hydrolase in an $n$-hexanol/buffer biphasic system. J Biotechnol. 2016;236:152-8.

\footnotetext{
Ready to submit your research? Choose BMC and benefit from:

- fast, convenient online submission

- thorough peer review by experienced researchers in your field

- rapid publication on acceptance

- support for research data, including large and complex data types

- gold Open Access which fosters wider collaboration and increased citations

- maximum visibility for your research: over $100 \mathrm{M}$ website views per year
}

At BMC, research is always in progress.

Learn more biomedcentral.com/submissions 